DOI: 10.36910/6775-2524-0560-2020-39-17

УДК: 004.771

Савицький Тимофій Павлович, магістрант,

Орлова Марія Миколаївна, к.т.н., доцент.

https://orcid.org/0000-0002-6617-4631

Національний технічний університет України «Київський політехнічний інститут імені Ігоря

Сікорського»

\title{
ВИКОРИСТАННЯ ШТУЧНОГО ІНТЕЛЕКТУ ДЛЯ СИСТЕМИ РОЗУМНОГО БУДИНКУ
}

Савицький Т.П., Орлова М. М. Використання штучного інтелекту для системи розумного будинку. Технології розумного дому та штучного інтелекту розвиваються швидко та в різних галузях науки. В статті розглянуто i проаналізовано способи та особливості побудови систем розумного будинку з використанням штучного інтелекту, детально розглянуто основні функції, які на сьогодні використовуються в системі розумного будинку та штучного інтелекту. Аналіз літератури та огляд продуктів даються для визначення функцій та ролей штучного інтелекту у системах розумного будинку. В роботі розглянуто моделі взаємодії користувачів, систем штучного інтелекту i модулів розумного будинку та аналізуються особливості їх використання. Визначається статус використання штучного інтелекту при розробці систем розумного дому і основні способи та напрямки його використання.

Ключові слова: штучний інтелект; функції штучного інтелекту; інтелектуальні взаємодії; розумний дім; ресурси розумного дому.

Савицкий Т.П., Орлова М. Н. Использование искусственного интеллекта для системы умного дома. Технологии умного дома и искусственного интеллекта развиваются быстро и в разных областях науки. В статье рассмотрены и проанализированы способы и особенности построения систем умного дома с использованием искусственного интеллекта, подробно рассмотрены основные функции, которые сегодня используются в системе умного дома и искусственного интеллекта. Анализ литературы и обзор продуктов даются для определения функций и ролей искусственного интеллекта в системах умного дома. В работе рассмотрены модели взаимодействия пользователей, систем искусственного интеллекта и модулей умного дома, а также анализируются особенности их использования. Определяется статус использования искусственного интеллекта при разработке систем умного дома, основные способы и пути его использования.

Ключевые слова: искусственный интеллект; функции искусственного интеллекта; интеллектуальные взаимодействия; умный дом; ресурсы умного дома.

Savytskyi T.P., Orlova M. M. Using Artificial Intelligence for a Smart Home System. Smart home and artificial intelligence technologies are evolving rapidly and in various fields of science. The article discusses and analyses the methods and features of building smart home systems using artificial intelligence. Literature analysis and product review are provided to determine the functions and roles of AI in smart home systems. Models of the interaction of users, artificial intelligence systems and smart home modules are considered in the work and the peculiarities of their use are analyzed. The status of the use of artificial intelligence in the development of smart home systems and the main ways and directions of its use are determined. smart home

Keywords: artificial intelligence; functions of artificial intelligence; intellectual interactions; smart home; resources of a

Вступ. В останні роки розвиток технології розумного дому сприяв переходу будинку від традиційного до інтелектуального за допомогою підключеного Інтернету. Розумний дім - це помешкання, оснащене технологіями, які включають датчики контролю навколишнього середовища, вхідними та вихідними даними і під'єднані до єдиного середовища [1]. Оснащені високотехнологічними автоматичними системами розумні будинки для зручності можуть відстежувати та контролювати домашні дії, забезпечувати мешканцям кращий комфорт та, можливо, заощаджувати споживання енергії. Технологія розумного дому збирає та аналізує дані з модулів, які входять до домашнього середовища. Він також передає інформацію користувачам і розширює потенціал управління різними системами [2].

Постановка наукової проблеми. Взаємодія штучного інтелекту 3 ресурсами розумного будинку стає все більш важливою у світі. В майбутньому розумним будинкам будуть приділяти все більше уваги взаємодії між людьми та навколишнім середовищем, щоб зробити будівлі більш стійкими та персоналізованими. Одним із важливих напрямків застосування штучного інтелекту для розумних будинків $\epsilon$ створення єдиного середовища застосування. Технологія штучного інтелекту використовується в управлінні пристроїв, управлінні енергією, в охороні здоров'я, в інтелектуальній взаємодії, безпеці, розважальних системах та персональних роботах, використовуючи розпізнавання діяльності, обробку даних, прийняття рішень, розпізнавання зображень, прогнозування та розпізнавання голосу. Але технологія штучного інтелекту, розумні будинки та користувачі мають різні моделі взаємодії. В основному, існує дві типи моделей взаємодії. Перший - користувачі безпосередньо дають команди кожному розумному домашньому пристрою, а штучний інтелект, 
вбудований у кожен пристрій, приносить користь саме конкретному пристрою. Другий - де користувачі дають інструкції штучному інтелекту, а штучний інтелект контролює кожен пристрій. У зв'язку з цим, буде розглянуто дві моделі застосування штучного інтелекту з розумним будинком.

Мета роботи полягає в аналізі існуючих рішень підвищення ефективності функціонування розумного будинку за рахунок використання штучного інтелекту, класифікації областей їх використання та розробці моделі ефективного використання енергії в будинку та спрощення системи управління ресурсами розумного дому.

Аналіз досліджень. Після аналізу літератури [4], [5], сформулюємо п'ять основних функцій розумного будинку, а саме: управління пристроями, управління енергією, охорона здоров'я, інтелектуальна взаємодія та безпека. Розділимо функції ШІ у розумних будинках на шість узагальнених

Device Management

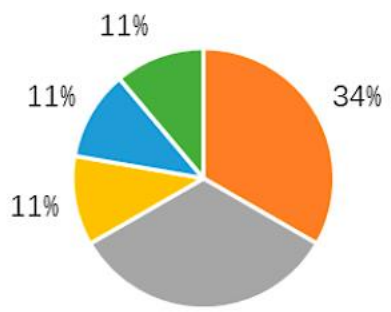

$33 \%$

- Activity Recognition = Data Processing " Decisions Making

- Image Recognition " Predictions Making " Voice Recognition

(a)

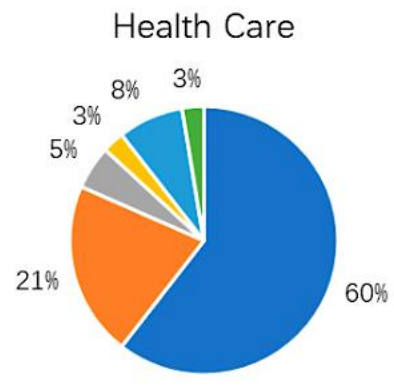

- Activity Recognition - Data Processing = Decisions Making

- Image Recognition = Predictions Making = Voice Recognition

(c)

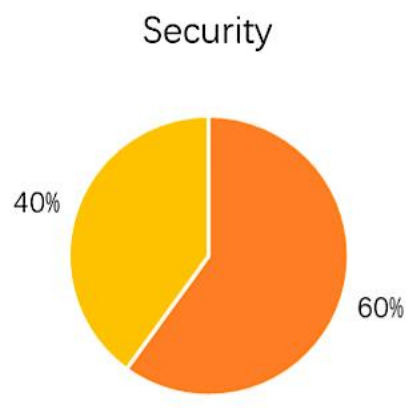

- Activity Recognition - Data Processing " Decisions Making

- Image Recognition - Predictions Making " Voice Recognition

(e)

\section{Energy Management}

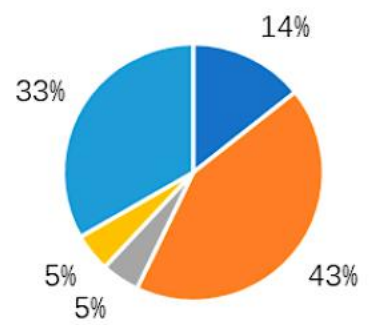

- Activity Recognition - Data Processing = Decisions Making

- Image Recognition " Predictions Making = Voice Recognition

(b)

Intelligent Interaction

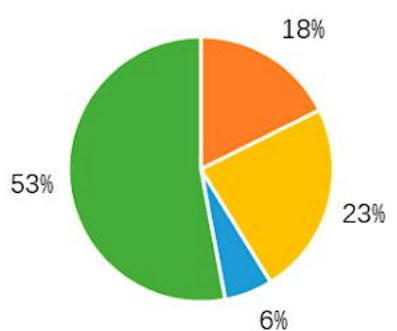

- Activity Recognition = Data Processing = Decisions Making

- Image Recognition " Predictions Making " Voice Recognition

(d)

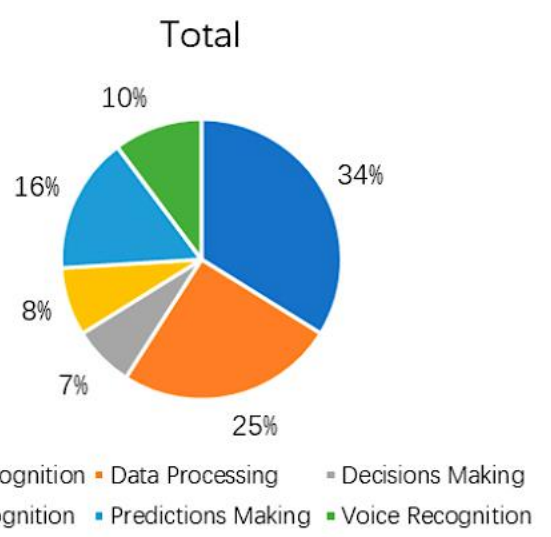

(f) 
Рис. 2. Кількість публікацій у різних галузях. а) Функції штучного інтелекту (ФШІ) в управлінні пристроями; b) ФШІ у сфері енергетики; с) ФШІ у сфері охорони здоров’я; d) ФШІ для інтелектуальної взаємодії; е) ФШІ у сфері безпеки; f) ФШІ для всіх функцій розумного будинку [6] кластерів діяльності людини: розпізнавання діяльності, обробка даних, прийняття рішень, розпізнавання зображень, прогнозування та розпізнавання голосу. У статті робота з даними включає обробку самих даних, семантичний аналіз та технології на основі правил управлінні розумного дому [6].

Як показано на рисунку 2a, управління розумним пристроєм домашнього пристрою підтримується п'ятьма функціями ШІ. На жаль, застосування ШІ в управлінні розумними пристроями не знайшли широкого висвітлення в описі літератури, оскільки $є$ достатньо новими. Управління енергією розумного будинку підтримується п'ятьма функціями ШІ: розпізнаванням діяльності, обробкою даних, прийняттям рішень, розпізнаванням зображень та прогнозуванням. ШІ для розпізнавання активності більш широко досліджується ніж попередні галузі. Інтелектуальна взаємодія розумного будинку підтримується чотирма функціями ШІ обробкою даних, розпізнаванням зображень, прогнозуванням та розпізнаванням голосу. 32012 року в цій галузі було багато досліджень, але більшість досліджень $\epsilon$ дуже новими. Безпека розумного будинку підтримується двома функціями ШІ: обробкою даних та розпізнаванням зображень. Решта досліджень, в основному, стосуються базових досліджень із застосування технології ШІ в розумному будинку. На рисунку $2 \mathrm{f}$ показана обробка даних та розпізнавання активності, які широко використовуються у всіх програмах розумного дому.

Виклад основного матеріалу та обгрунтування отриманих результатів. Технологія штучного інтелекту (ШІ) використовується в продуктах розумного дому. Для структуризації найбільш поширених функцій, які на сьогодні використовуються, визначимо шість основних кластерів функцій ШІ у розумних будинках, а саме: розпізнавання діяльності користувачів, обробка даних, розпізнавання голосу, розпізнавання зображень, прийняття рішень та формулювання прогнозу подальших дій. В аспекті розпізнавання активності пристроїв розумного будинку можуть розпізнавати діяльність людини за допомогою ШІ [3], який аналізує дані сенсорів, щоб виявити дії людей i формує сигнал тривоги, якщо $є$ аномальна активність. В аспекті обробки даних ШІ заснований на зчитуванні інформації 3 різних модулів, методах аналізу даних та виявленні внутрішніх взаємозв'язків між ними. В системі розумного будинку на основі ШІ використовується модуль розпізнавання голосу для управління різними ресурсами. Наприклад, розпізнавання голосу використовується в Apple HomePod, Amazon Alexa, Athom Homey, Google Home та ін [3]. В аспекті розпізнавання зображень Ш використовується для розпізнавання обличчя, емоцій, біометрики та аналізу навколишнього середовища. Він може вимірювати та аналізувати поведінку людини, а також фізичні структури та форми тіла. ШІ може вирішити, які дії слід вжити у відповідь на вхідні дані [4]. Наприклад, у інтелектуальній системі безпеки, якщо камера виявить незнайомця, який проникає в будинок, вона спрацьовує гучним сповіщенням та подає попередження на смарт-телефон користувача або він може зателефонувати 102. Ці системи повинні бути досить швидкими та ефективними. Дані датчиків збираються комп'ютерною мережею і зберігаються у базі даних для оброблення інтелектуальним агентом, що генерує корисні знання, такі як закономірності, прогнози та тенденції. На основі цієї інформації розумний дім із ШІ може вибирати та автоматизувати дії для досягнення цілей програми розумного дому [5].

Аналіз інтересу до розумного будинку та штучного інтелекту показує, що вся взаємодія між пристроями та застосуванням ШІ виконується на двох рівнях. На сьогодні доступно багато рішень та розумних домашніх ресурсів, які мають низький рівень взаємодії між різними пристроями, серед них пристрої, які визначають параметри навколишнього середовища та управління будинком. Були спроби створення застосування високого рівня взаємодії продуктів розумного дому.

На рисунку 1 представлено тенденцію розвитку технології продуктів розумного дому та Ш. 


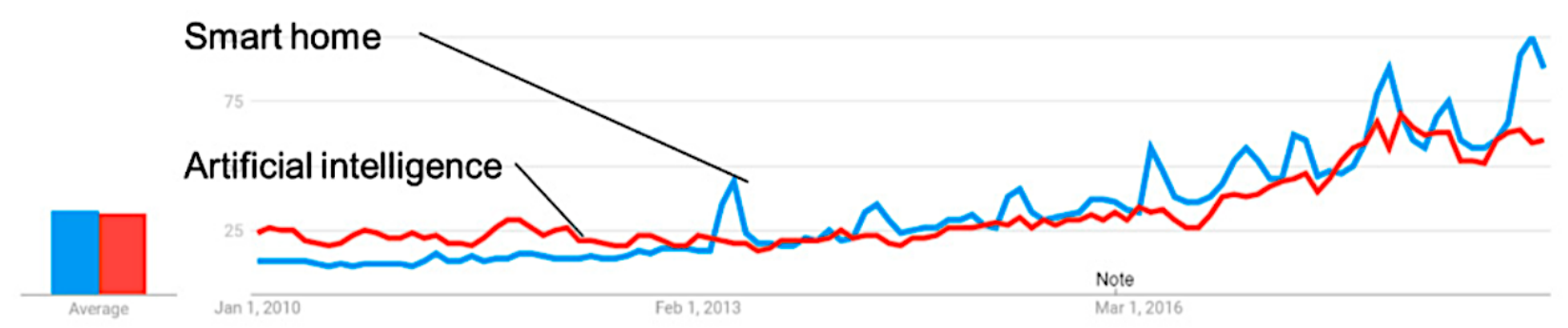

Рис. 1. Інтерес до розумного будинку та штучного інтелекту

Розподіл розумних будинків в області застосування ШІ показано на рисунку 3 . У сукупності ці результати показують, що з часом обговорювалося все більше і більше областей застосування, i ці результати показують, що все більше обговорюються прикладні області використання ШІ. 32015 року активно почався розвиток ШІ у сфері охорони здоров'я. Дослідження управління енергетикою зменшувалися 3 кожним роком, тоді як дослідження інтелектуальної взаємодії з кожним роком збільшувалися. Розглянемо результати п'яти областей застосування ШІ до розумного дому, а саме: управління пристроями, управління енергією, охорона здоров'я, інтелектуальна взаємодія та безпека.

По-перше, що стосується управління розумними пристроями дому, 3 прогресом технологій кількість електричних приладів у будинку зростає, а етапи роботи стають все складнішими. На жаль, ШІ не може допомогти користувачам автоматично керувати пристроями. Деякі дослідники впроваджували ШІ в системах розумного будинку для контролю та управління ресурсами в будинку, автоматично

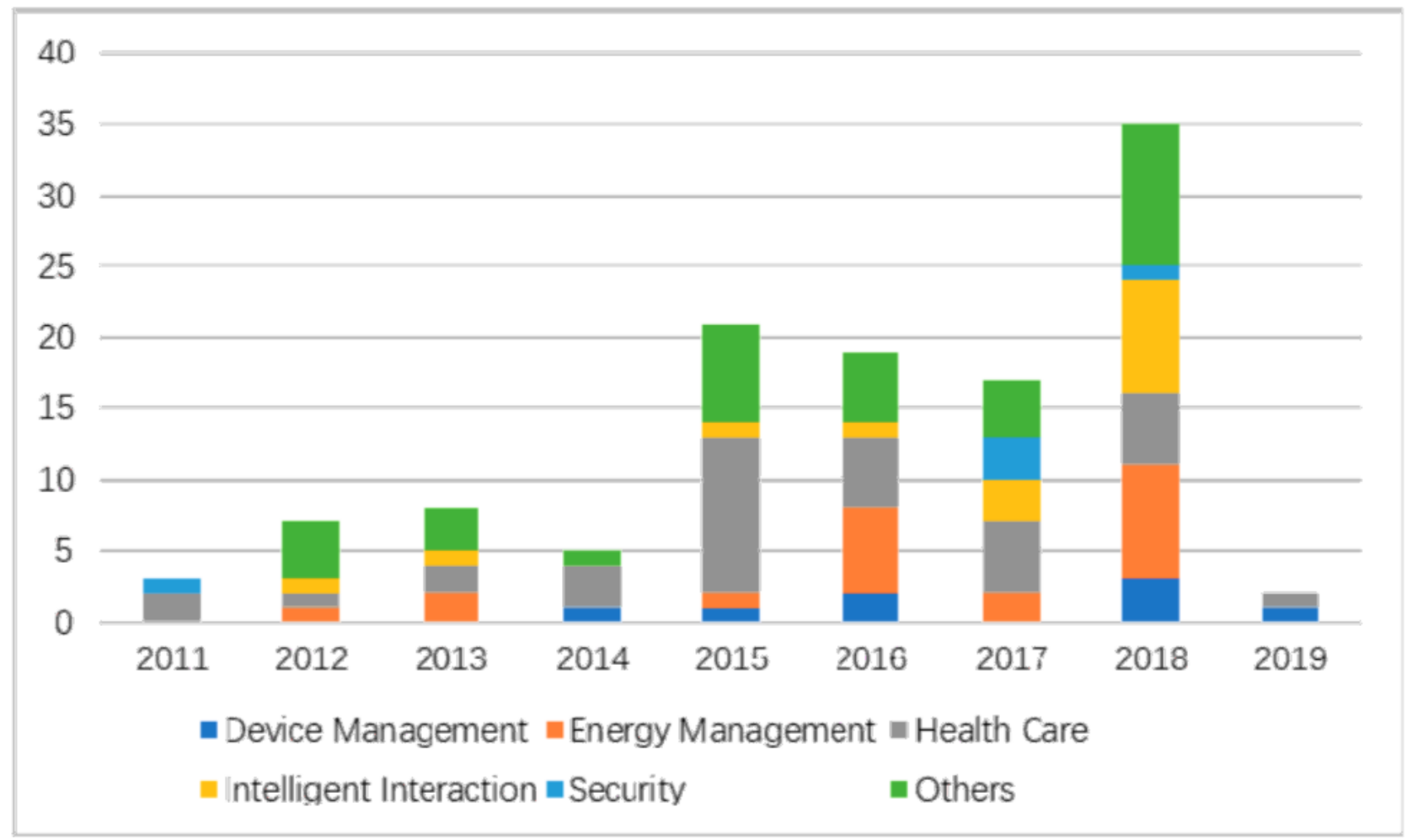

Рис. 3. Поля застосування розумних будинків з ШІ

контролюючи світло і температурні умови [7]. Інтелектуальне управління в розумному будинку також може бути реалізовано шляхом аналізу даних сенсорної мережі, вивчення попередньої поведінки користувача [7] або моделей користувачів, застосовуючи алгоритм логістичної класифікації, заснований на TensorFlow [8]. Централізоване управління може приймати електронні рішення, такі як моніторинг, підвищення комфорту, зручності, контроль навколишніх умов та надання необхідної інформації [8]. 
По-друге, управління енергією розумного будинку стає все більш важливим та нагальним для суспільства. Люди з різних галузей наполегливо працюють над зменшенням споживання енергії та підвищенням енергоефективності. Координація споживання енергії розумних приладів у розумних будинках може досягти більшої ефективності споживання [9]. Шаблони споживання енергії та їх взаємозв'язок із чинниками навколишнього середовища можуть бути проаналізовані ШІ для прогнозування щоденної потреби в електроенергії [9]. ШІ може допомогти середовищу розумного будинку у визначенні поведінки споживача енергії, щоб підтримати автоматизацію будинку та зменшити споживання енергії [9]. Розпізнавання діяльності ШІ також може допомогти зв'язати діяльність та існуючу побутову техніку, а потім дати рекомендації користувачам кожного разу, коли він виявить енергетичні покращення [9].

По-третє, що стосується інтелектуального догляду за домом, то з поступовим збільшенням тривалості життя охорона здоров'я стає все більш важливою. Використовуючи методи машинного навчання та штучного інтелекту за сенсорними даними, можна відстежувати та виявляти зміни у поведінці та способі життя людей [10]. Використовуючи алгоритм кластеризації без нагляду, модель періодичної нейронної мережі та генетичний алгоритм, системи ШІ можуть постійно контролювати людей похилого віку в розумних будинках та надсилати попередження спостерігачу, якщо виникають нетипові дії [10].

По-четверте, відносно інтелектуальної взаємодії модулів розумного дому, враховуючи, що кількість розумних домашніх пристроїв постійно збільшується, інтелектуальна взаємодія може змусити користувачів відчувати себе більш комфортно. Більше не потрібно підходити до кожного пристрою, щоб керувати ним вручну. Більшість дослідників використовували штучні нейронні мережі для класифікації входів користувачів для створення природного діалогу, надаючи користувачам можливість керувати приладами голосовими чи текстовими командами [11]. Розпізнавання голосу на основі ШІ використовує технологію взаємодії на основі аудіо, яка дозволяє користувачам мати повний контроль над домашнім середовищем [11]. Розпізнавання зображень також допомагає ШІ зрозуміти жести людей. Взаємодія людини та комп'ютера на основі жестів $\epsilon$ природною та інтуїтивно зрозумілою. Люди з порушеннями мови можуть спілкуватися з розумними домашніми пристроями за допомогою динамічних жестів [11].

I останне, з точки зору безпеки розумного будинку, для захисту власності та особистої безпеки необхідно забезпечити будинок від несподіваних подій та аварій. Штучний інтелект розпізнавання зображень може розпізнати зловмисника та попередити власника будинку [12]. Небезпека буває різною: пожежі, $\mathrm{CO}_{2}$ тощо. Ш може бути використаний для аналізу даних 3 датчиків та створення звуків тривоги [12].

Технології ШІ, розумні будинки та користувачі мають різні моделі взаємодії. В основному, існує дві типи моделей взаємодії. Перший показаний на рисунку 4а, де користувачі безпосередньо дають команди кожному розумному домашньому пристрою, а ШІ, вбудований у кожен пристрій, приносить користь саме конкретному пристрою. Розумне управління будинком, охорона здоров'я та безпека надають перевагу цій схемі. Друга модель зображена на рисунку $4 \mathrm{~b}$, де користувачі дають інструкції Ш, а ШІ контролює кожен пристрій. Розумне управління домашнім пристроєм та інтелектуальна взаємодія працюють за цією схемою.

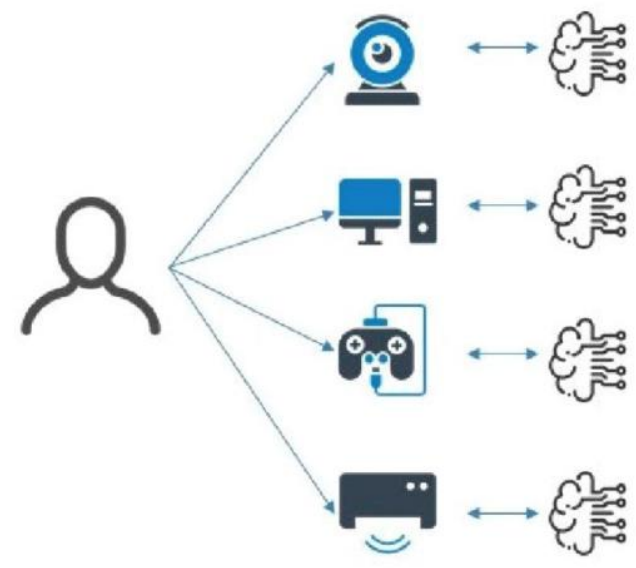

(a)

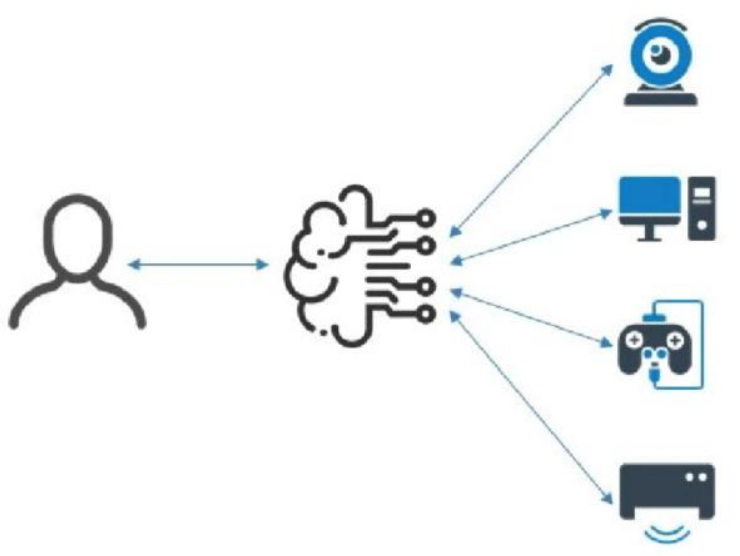

(b) 
Рис. 4. а) Перша модель користувачів, ШІ та розумних будинків; b) другий зразок користувачів, ШІ та розумних будинків.

Отже, якщо використовувати другу модель взаємодії між користувачами, розумним будинком та ШІ, то підвищується ефективність взаємодії за рахунок створення єдиної екосистеми. Користувачі формують і передають команди в екосистему, а система штучного інтелекту аналізує ці команди, стан пристроїв розумного будинку і взаємодіє зі всіма ресурсами розумного будинку одночасно.

Висновки. В роботі розглянуто взаємозв'язок способів штучного інтелекту та їх застосуванням при створенні систем розумного будинку. Проаналізовано різні області використання штучного інтелекту, функціональні особливості систем зі ШІ, що розробляються деякими компаніями. Доведено, що технологія штучного інтелекту допомагає розумним будинкам в управлінні пристроями, управлінні енергією, охороною здоров'я, інтелектуальній взаємодії, безпеці, розважальних системах та персональних роботах, використовуючи розпізнавання діяльності, обробку даних, прийняття рішень, розпізнавання зображень, прогнозування та розпізнавання голосу. Показано, що на сьогодні системах розумного будинку зазвичай використовуються доволі прості методи штучного інтелекту, такі як розпізнавання зображень і голосу.

Проведене в даній роботі дослідження доводить необхідність використання способів штучного інтелекту при створенні розумного будинку для управління всіма його ресурсами, що дозволить створити єдину екосистему розумного будинку та розробити єдиний архітектурний дизайн управління.

\section{Reference}

1. Trivodaliev, K.V.; Risteska Stojkoska, B.L. A Review of internet of things for smart home: Challenges and solutions. J. Clean. Prod. 2016, 127, 454-464.

2. Norvig, P.; Russell, S. Artificial Intelligence: A Modern Approach, 2rd ed.; Prentice Hall Press: Upper Saddle River, NJ, USA, 2007.

3. Min, G.; Rho, S.; Chen, W. Advanced issues in artificial intelligence and pattern recognition for intelligent surveillance system in smart home environment. Eng. Appl. Artif. Intell. 2011, 23, 1287-1290.

4. Fritz, R.; Dermody, G. A Conceptual framework for clinicians working with artificial intelligence and health-assistive smart homes. Nurs. Inq. 2019, 25, 2-9.

5. Kumar, S.; Abdul Qadeer, M. Application of AI in home automation. Int. J. Eng. Technol. 2013, 4, 913-917

6. Mouftah, H.T.; Qela, B.; Observe, learn, and adapt (OLA) - An algorithm for energy management in smart homes using wireless sensors and artificial intelligence. IEEE Trans. Smart Grid 2014, 3, 1788-1802

7. Wardana, I.N.K.; Crisnapati, P.N.; Aryanto, I.K.A.A. Rudas: Energy and sensor devices management system in home automation. In Proceedings of the 2016 IEEE Region 10 Symposium (TENSYMP), Bali, Indonesia, 9-11 May 2016; pp. $184-187$.

8. Park, M.H.; Ju, Y.W.; Jang, Y.H.; Park, S.C. Design of tensorflow-based proactive smart home managers. Lect. Notes Electr. Eng. 2019, 503, 94-105.

9. Jithish, J.; Sankaran, S. A Hybrid adaptive rule based system for smart home energy prediction. CEUR Workshop Proc. 2018,1720

10. Liouane, Z.; Roose, P.; Lemlouma, T.; Weis, F.; Messaoud, H. A Genetic Neural Network Approach for Unusual Behavior Prediction in Smart Home; Abraham, A., Franke, K., Köppen, M., Eds.; Springer: Berlin/Heidelberg, Germany 2018; Volume 2, pp. 942-969.

11. Li, Y.; Su, H.; Liu, L. Gesture Recognition Based on Accelerometer and Gyroscope and Its Application in Medical and Smart Homes; Springer International Publishing: New York, NY, USA, 2019; Volume 9983, pp. 61-71.

12. Wicaksono, W.R.; Surantha, N. Design of smart home security system using object recognition and PIR sensor. Procedia Comput. Sci. 2019, 89, 320-322. 